Удк 248.35.27

T.Busarieva,

$\mathrm{PhD}$ in Economics, Associate Professor, Specialist for ensuring

the work of the Supervisory Board of NPC "Ukrenergo"

ORCID ID: 0000-0003-3863-4511

\title{
TRANSFORMATION OF NEW ECONOMY FROM "HOMO ECONOMICUS" TO "HOMO CORPORATIVUS"
}

\author{
Т. Г. Бусарєва, \\ к. е. н., доцент, фахівець по забезпеченню роботи, Наглядова Рада НЕК "Укренерго"
}

\author{
TРАНСФОРМАЦІЯ НОВОÏ ЕКОНОМІКИ ВІА "НОМО ЕСОNOMICUS" АО "HOMO \\ CORPORATIVUS"
}

\begin{abstract}
Against the background of global technological changes and structural restructuring of the world economy, the creation of new models of economic development, characterized by high growth rates and a share of intellectual capital, comes to the fore. The nature of the causal relationship should be interpreted as follows: this global trend determines the paradigm of the economy, and the paradigm of the economy - the nature, features of the era, social paradigm, the nature of the post-industrial era. It is the paradigm of economics that is the criterion for determining the nature of the historical epoch and the corresponding social paradigm. It is justified to introduce into scientific practice the principle of similarity, conformity of paradigms. On its basis, in particular, it can be argued that the paradigm shift of the economy leads to a change in the social paradigm, the social nature of the era. Moreover, the social paradigm must be adequate to the paradigm of the economy. In addition, it causes a change in the previous paradigms of all levels in their hierarchy. It is worth noting that the paradigm of the economy of pre-industrial society corresponds to the general and higher in the hierarchy paradigm "Man - a child of nature." In the preindustrial era, natural agricultural production prevailed, man could not survive without involvement in the agricultural process. Man as a link in the biological cycle of nature was forced to adapt and compare their actions with the biological rhythm of agricultural production. In the traditional view, it is expedient to distinguish three system-historical types of industrial economic growth: early industrial, mature industrial and late industrial. If the representatives of early industrial growth in organizational and institutional terms were mainly firms that were in individual private ownership or in the form of partnership, then mature industrial growth is based on corporate private ownership in the form of joint stock companies, where capital-ownership and capital-function are largely separated. From the context of research, it can be argued that the cost will increasingly be determined not by production costs but by research costs. That is why the modern paradigm of economics is in fact a new formulation of the basic law of economics - the law of value: the cost will be equal to the cost of research, in particular post-industrial society - a research society. It is characterized by an unprecedented shift of emphasis from production to research and the peculiarities of the transformation of the new economy from "homo economicus" to "homo corporativus".
\end{abstract}

На тлі глобальних технологічних зрушень і структурної перебудови світової економіки на перший план висувається створення нових моделей економічного розвитку, що відрізняються високими темпами зростання та часткою інтелектуального капіталу. Характер причинно-наслідкового зв'язку необхідно трактувати так: зазначена світова тенденція визначає парадигму економіки, а парадигма економіки - характер, особливості епохи, соціальну парадигму, характер постіндустріальної епохи. Саме парадигма економіки є критерієм визначення характеру історичної епохи та відповідної їй соціальної парадигми. Виправданим є введення в наукову практику принципу подібності, відповідності парадигм. На його основі, зокрема, можна стверджувати, що зміна парадигми економіки веде і до зміни соціальної парадигми, соціального характеру епохи. Причому соціальна парадигма повинна бути адекватною парадигмі економіки. Крім того, це спричиняє зміну попередніх парадигм усіх рівнів в їх ієрархї̈. Доцільно зазначити, що парадигмі економіки доіндустріального суспільства відповідає загальна і вища в ієрархії парадигма "Людина -дитина природи". В доіндустріальну епоху панувало натуральне сільськогосподарське виробництво, людина не могла про- 
існувати без залучення до землеробського процесу. Людина як ланка біологічного циклу природи змушена була підлаштовуватися та порівнювати свої дії з біологічним ритмом сільськогосподарського виробництва. В традиційному уявленні доцільно виокремити три системно-історичні типи індустріального економічного зростання: ранньоіндустріальний, зрілий індустріальний та пізньоіндустріальний. Якщо представниками ранньоіндустріального зростання в організаційно-інституціональному плані переважно були фірми, що знаходилися в індивідуальній приватній власності або у формі партнерства, то зріле індустріальне зростання спирається на корпоративну приватну власність у формі акціонерних товариств, де капітал-власність і капітал-функція багато в чому розділені. 3 контексту досліджень можна стверджувати: вартість все більшою мірою буде визначатися не витратами виробництва, а витратами дослідження. Саме тому сучасна парадигма економіки - це фактично нове формулювання основного закону економіки - закону вартості: вартість буде дорівнювати витратам дослідницької праці, зокрема постіндустріальне суспільство - це дослідне товариство. Для нього характерним є безпрецедентне досі перенесення акценту з виробництва на дослідження та особливостей трансформації нової економіки 3 "homo economicus" y "homo corporativus".

Key words: transformation, new economy, corporatization, corporatist, new ideology.

Ключові слова: трансформація, нова економіка, корпоратизація, корпоративіст, нова ідеологія.

\section{FORMULATION OF THE PROBLEM}

In today's economy and society, intangible resources are of unprecedented importance, and the key to socioeconomic progress in the information age is the activation of intellectual and human potential at all levels of social life and especially at the level of individual corporations, where there is a need for a highly professional approach to human resources management. This is due to the fact that, taking a new place in the production process, intellectual workers can no longer be guided by traditional methods. In an environment where social relations become a sphere of personal aspirations rather than bureaucratic regulation, and the imagination and creativity of man become a limitless resource for solving production problems, the compatibility of values, worldviews and goals is more important than the details of a particular commercial agreement. Therefore, in a modern corporation, neither party - neither employees nor entrepreneurs - is neither "dependent" nor "independent", they are "interdependent". In the 1930s, the conventional neoclassical concept of economic man was subject to different kinds of criticism. One contribution that so far has not been consistently scrutinised was presented by the economic doctrine of corporatism, which was particularly influential in Southern European countries.

\section{ANALYSIS OF RECENT RESEARCH AND PUBLICATIONS}

The following foreign scientists have made a significant contribution to the study of the processes of formation, development and analysis of the transformational activity of transnational corporations: K. Akamanu, P. Buckley, R. Barnet, J. Galbraith, J. Dunning, J. Dibold, P. Drucker, W. Dumsza, M. Quezon, R. Coase, E. Lernd, P. Lindert, J. McDonald, R. Mueller, R. Narulla, F. Nickerbrocker, P. Nueno, G. Parker, A. Ragman, S. Rolf, B. Scott, R. Stobauch, J. Stopford, L. Turner, M. Wilkins, L. Wells, M. Holman, K. Christensen, N. Hood, A. Chandler, S. Young. However, despite the significant achievements of foreign and domestic scientists in this field, the problems of forming the corporate direction of development of the new economy remain insufficiently disclosed.

\section{FORMULATION OF THE PURPOSE OF THE ARTICLE}

The purpose of this article is to analyze the peculiarities of the formation and transformation of new economy from "homo economicus" to "homo corporativus".

\section{PRESENTING MAIN MATERIAL}

Based on the analysis, we propose the following system of correlation of these categories: the basic concept is the theory of post-industrial society; all subsequent theories are a concept of post-industrial economy with the use of one of the features as a key element of the economy. The first concept is the theory of service economy, which was transformed into the information economy. The theory of information economy, on the one hand, has developed into an innovative economy through a synthesis of theories of human capital. On the other hand, in the digital economy as a result of the digital revolution. Network economics contains all these theories. The concept of post-industrial economy is primarily a theoretical model, the purpose of which was to predict possible options for the development of a new economy formed at the beginning of the XXI century, based on the real economy of developed countries. The fif th change in the technological structure, based on the sixth information revolution, prompted the search for theorists and practitioners of a new ideology, a paradigm of world civilization, which they began to interpret as the information society, knowledge economy, post-industrial economy, infosphere, programmed society.

The new ideology, the new economy must be based on a methodological approach, taking into account two fundamentally different components compared to the previous epistemological achievement. The first component is the recognition in the cognitive object of an active conscious beginning, already possesses some information and has a set of psychological properties adequate to modern economic society, which allows the latter to respond to the changing competitive environment. The second component (it should be noted that economists have ignored it until recently) is the recognition in people of properties and goals that go beyond the narrow utilitarian boundaries by which economists traditionally 
distinguish their analytical constructions, and the inclusion of active reflective models first in cognitive activity and then and in management decisions. The subject of work is information technology, and economics - human consciousness, which is manifested in various manifestations [1, p. 83-90].

The term "new economy" has been widely used since the early 2000 s. The first attempts to explain the phenomenon of the new economy appeared in 1976 in the works of the American Stanford Center M. Porat and M. Rubin, which highlighted the significant and rapidly growing sector of the information economy and developed a system of basic concepts and methodology for studying the impact of the information sector. to other sectors of the economy. According to the first approach, the "new economy" means a complex of knowledge-intensive industries engaged in the production and provision of information and communication equipment, creation and distribution of software products, development of communication networks, and the entire system of formation, storage, dissemination and retrieval of information on the Internet. According to this approach, the "new economy" includes all business activities that use modern electronic information and communication technologies.

The second approach includes in the concept of "new economy" organizational and institutional innovations in the activities of various (including traditional) sectors of the economy of developed countries. This definition is presented in the concept of the Council of Economic Advisers under the President of the United States, according to which the American economy of the last decade of the twentieth century is generally characterized as a "new economy" due to extraordinary growth, as a result of the combined effect of technology. practice and economic policy [2, p.120-125].

Proponents of the third approach pay attention to the financial component of the "new economy". This approach defines the concept as one of the peaks of the international financial economy, the financial model of management, which symbolizes the widespread use of tools of information technology innovation in the monetary and financial system. Within the framework of these approaches, important elements of the new economic reality created by information technologies at both sectoral and national levels are in the field of view of researchers. However, these interpretations of the "new economy" do not sufficiently reveal the dynamics of the current stage of social progress.

The fourth approach considers the "new economy" as a set of industries characterized by a larger share of human capital compared to material elements. In these areas, the technological implementation of knowledge plays a crucial role, and the production of knowledge is a source of economic growth. In this interpretation, the concept includes the field of education, information and communication markets, innovation, the provision of intellectual services (consulting, information mediation, analytics, marketing). In the new economy there are two subspaces that define the different activities of economic relations: material (includes the actual processes of creation, distribution and consumption of resources) and information (is the result of information reflection of material space, includes the formation of information model environment and composition) ), and on its basis - a new way of material space [3, p. 431-450].

It is expedient to single out the factors that led to the emergence and development of the new economy, including the globalization of the economy, characterized by free trade and market liberalization, increased capital mobility, lower corporate income taxes, ease of industry between states to reduce labor and natural resources; creation and distribution of networks, general informatization; creation of new forms of employment and remuneration, work through a system of remote offices; dissemination of skilled and intellectual work; rapid development of technology and technology. The most important factor in the existence of a new economy is knowledge, which becomes an independent factor in production. The peculiarity of this factor is belonging to intangible, inexhaustible and non-scarce resources.

In the formation of a new economy, economists are paying more attention to the role of the individual in economic processes, including the production of new knowledge (French and English schools of neoinstitutionalism), market agent behavior (rational choice theory and transaction costs) and consumer decision making (rational choice theory). Representatives of preindustrial, industrial and post-industrial economies considered certain aspects of the economy of the individual, without linking them to the theory of noosphere development. However, in the new economy, human knowledge, ie homo economicus, plays a decisive role, despite the fact that the new economic system is based on moral, religious and historical principles, but still focuses on new forms of scientific legitimation [4, p. 56-57].

Summarizing the above, it is worth emphasizing that the key role in understanding modern problems is played by the creation of a fundamentally new theory of economic and technological development, its value criteria and indicators. Traditional ideas based on the resource components of growth and measuring its incremental values of production, income, production have exhausted themselves. The main economic parameter of the country is the productivity of industry as a total parameter of productive technologies. Under such conditions, science truly becomes a productive force. Thus, the theory of labor value passes into the theory of technological value and exchange. This calls for the creation of political economy the theory of economic and technological development. Taking into account the diversity of the political system (modification of property relations, mixed type of economic system, class structure of society) does not deny the existence of common collective characteristics for productive technologies associated with global trends of economic and technological progress. In the structure of social reproduction, increasing the importance of the information component of economic, technological development, environmental and social constraints imposed on it, increasingly calls into question the universality of the labor theory of value in the explanation of social processes. It loses its absolute significance and becomes a "special case" applied to a certain stage of socio-economic progress, characterized by relatively smooth development with the predominant or exclusive use of traditional growth factors [5, p. 43-61]. 
In the context of modern theories, economists substantiate the current corporate experience, namely the economic strategy of maintaining economic and social balance, which prevailed until the end of World War II. The main assumption was that the new corporate system would be seen as an alternative to capitalism and socialism. That is why at the beginning of the XXI century scientists are trying to build an economic theory of the third system, which would avoid the negatives of a socialist planned economy (lack of individual freedom) and social errors inherent in the system of liberal capitalism (extreme competition, poverty, resource consumption). It should be noted that at the beginning of the XXI century, this view is shared by many scientific schools and economists, who insisted on the benefits of the "third way", maintaining a critical distance in the loss of political freedom and individual rights, which was a typical feature of fascist and similar regimes.

Therefore, the experiments of corporatists were positively assessed by those who believed that the class struggle was not an inherent condition of capitalist, economic and social organization - in terms of ownership of means of production or distribution of income - that is, those who suggested that the interaction between capital and labor was the driving force any developed economy and society. Among the basic concepts of classical and neoclassical economics, proponents of the doctrine of corporatism directly question the economic theories associated with the concept of natural equilibrium, such as market price and market wages. Their attention was instead focused on determining the corporate price, the salaries of corporate employees and building a new theory of distribution [6, p. 22-27].

Despite the common goals, there were some important differences between the approaches to the functioning of the new economic system. Some economists, who had closer ties to the neoclassical tradition, took for granted a version of "homo economicus," that is, an economic individual who is interested, rational, unchanging, detached, and non-reflective. Proponents of this vision saw "homo economicus" as the main tool of economic analysis, although they also saw the state and the corporatist bureaucracy as necessary and appropriate institutions to regulate economies that would inevitably arise from the behavior of individual economic agents with limited sense of common good. In this sense, it was argued that the complex scientific developments of economics from the classical school to the present cannot be ignored, bearing in mind that, after all, corporatism was nothing more than a doctrine recognizing the need to limit or mitigate economic factors and impulses. also the tension of economic policy.

From our point of view, the market economy of the state is endowed with the mission of ensuring moderation and balance, which could not be done spontaneously through a system of free competition. Preventing the formation of trusts and cartels, supervising undesirable monopolistic methods, creating tools to promote and regulate competition between economic agents of the goal is the most appropriate and fair. Reforming proposals of a moderate liberal nature consisted in his epistemological attitude to the acceptance of the principle that the cate- gories of traditional economic analysis not only remained inviolable, but in fact they were necessary for the classification and understanding of the phenomena of the corporate economy. Corporatism represented not only a new economic and social order, but also a new scientific method for explaining economic life, the main arguments of which were based on a harsh critique of homo economicus, defending the principle that there is a perfect identity between the individual and the state. This basic philosophical principle differs from the logical positivism and individualism inherent in the mainstream neoclassical economy, according to which certain interests can be achieved only through the realization of national interests, a kind of general will be honestly interpreted by the state [7, p. 54-60].

"Homo corporativus" differs from "homo economicus" not only in that it is socially oriented towards belonging to communities, but also in that it is guided by the notion of social interest of both corporations and the state. This concept is considered to be changeable because it is influenced by idealistic values and moral considerations. This construction is part of a broader approach to the process of socialization (with the inherent concept of homo sociologicus) and explains how internalized norms become people's motivation. That is, it is not enough to trust the virtues of selfish behavior and self-interest to explain what motivates rational agents to action.

The statement that social life is the interaction of rational people should be supplemented by the idea of the existence of social norms followed by different people in a given society, which leads to the understanding of individual rational behavior as an expression of self in the social world, promoting coordination, cooperation and social harmony. In this sense, it can be noted that the corporatist movement plays a role in changing the atomistic concept of individual behavior, which characterizes the neoclassical economy as part of a broader view of the individual. As for the doctrine of corporatism, rationality is viewed in a broader institutional context where people operate within a corporation. Such was the new integral destiny of homo corporativus.

The vast majority of corporatist economists have recognized that it is difficult to radically change human nature (despite intense propaganda in favor of such a change) for all people to sacrifice their specific interests for the common good. The idea of man rejects the hedonistic principle and is guided by his personal interests in the way of the affect of societies. Difficulties in constructing the original body of corporatist theory become apparent when we observe that none of the textbooks on corporatist economics published during this period made any attempt to develop a theory based on the concept of homo corporativus. Indecision and ambiguity in addressing key doctrinal issues have also led to other attempts to theoretically define the third method. His supporters reduced the importance of a rational personality to a minimum and sought to consider social groups and collective organizations. Some ideologues of corporatism have paid much attention to the concept of self-governing economy, which has nothing to do with the mechanisms that led to the spontaneous equilibrium of the market [8, p. 178-195]. 
In our view, in a corporatist economy, corporations must regulate economic activity through a complex system of bilateral monopoly markets. Thus, a high degree of state intervention was envisaged when the corporationist organization was first founded, after which the importance of such a protagonist would gradually diminish. The impetus for the creation of corporations embodied the logic of socio-economic organization, in which the realization of the common interest was previously measured by reconciling the interests of different agents and groups of agents operating in a market controlled by the state.

Fixation of prices, entry of new firms into the market, regulation of working conditions, determination of wages, analysis of production costs, in general, all operations involving the use of economic calculation, and in a system of free competition are basic selection procedures in the context of scarcity of available resources. for homo economicus decisions mentioned in the neoclassical economic literature) - all these features would be a privileged area for corporations and federal employers' organizations (guilds). Guilds allow corporations to increase national representativeness and provide horizontal control over activities related to a particular product (wheat, rice, olive oil, wool, wine, etc.) [9, p. 21-26].

Thus, the "new economy" is characterized by the following features: knowledge forms most of the added value; knowledge, innovation and creativity are economic categories; work with knowledge is allocated to a separate area of activity; communications play a significant role and stand out in a separate sector of the economy; hierarchical management system is transformed into complex network structures.

\section{CONCLUSIONS}

The new paradigm of economic theory is designed to explore the patterns of formation and development of the knowledge economy, to integrate the conceptual development of all theoretical areas of their study. If theoretically the post-industrial society, information, network and innovation economies solve the problems of forming the basis of the system of "new economy", the theory of knowledge economy is aimed at the social, institutional aspect of its formation. The growing relationship between capital markets and new technologies, strengthening the social orientation of new technologies, the large-scale nature of the creation and use of knowledge, technologies, products and services lead to increasing the role of national innovation systems as an institutional basis for innovation and knowledge economy. It is important to note that the developed intellectual capital, focused on intensive innovative development, is a necessary condition for the competitiveness of economic entities. In the context of the crisis of the world economic system, the problem of improving the processes of intellectual capital formation is becoming even more acute. After all, the transition from an industrial society to a new economy and the intensive development of information and communication technologies have significantly increased the role of intellectual capital compared to the role of financial and physical. The bearer of intellectual capital, embodied in the creative competencies of man, is a modern highly qualified professional. It produces and sells intellectual capital in the form of inventions, trademarks, information databases, models, know-how necessary to achieve a leading position by economic entities at the present stage of market economy development. This determines the urgency of solving the problem of formation of intellectual capital, taking into account the requirements of the knowledge economy.

\section{Література:}

1. Chowdhury S. Organization 21C: Someday All Organization Will Lead This Way. Prentice Hall. 2019. P. 83-90.

2. Davenport T.H., Prusak L. Working Knowledge. Boston: Harvard Business School Press, MA, 2020. P. 120-125.

3. Despres C., Chauvel D. Knowledge Horizons. Newton: Butterworth-Heinemann, MA. 2020. P. 431-450.

4. Drucker P. Planning for uncertainty. The Wall Street Journal (June 22). 2018. P. 56-57.

5. Fuller S. Knowledge Management Foundations. Newton: Butterworth-Heinemann, MA, 2019. P. 43-62.

6. Ivancevich J., Duening T. Managing Einstein's. Leading High-Tech Workers in the Digital Age. N. Y.: McGraw-Hill, 2020. P. 22-27.

7. Liebowitz J., Beckman T. Knowledge Organizations. St. Lucie Press. 1998. P. 54-60.

8. Nonaka I., Takeuchi H. The Knowledge Creating Company: How Japanese Companies Create the Dynamics of Innovation. N.Y.: Oxford University Press, 1995. P. $178-195$.

9. Penrose E. The Theory of the Growth of the Firm. 3rd ed. Oxford: Oxford University Press, 2018. P. 21-26.

\section{References:}

1. Chowdhury, S. (2019), Organization 21C: Someday All Organization Will Lead This Way, Prentice Hall, Hoboken, USA, pp. 83-90.

2. Davenport, T. H. and Prusak, L. (2020), Working Knowledge. Boston: Harvard Business School Press, MA, pp. $120-125$.

3. Despres C. and Chauvel D. (2020), Knowledge Horizons, Butterworth-Heinemann, Newton, USA, pp. $431-450$.

4. Drucker, P. (2018), "Planning for uncertainty", The Wall Street Journal, vol. June 22, pp. 56-57.

5. Fuller, S. (2019), Knowledge Management Foundations, Butterworth-Heinemann, Newton, USA, pp. $43-62$.

6. Ivancevich, J. and Duening, T. (2020), Managing Einstein's. Leading High-Tech Workers in the Digital Age, McGraw-Hill, N. Y., USA, pp. 22-27.

7. Liebowitz, J. and Beckman, T. (1998), Knowledge Organizations, St. Lucie Press, St. Lucie, USA, pp. $54-60$.

8. Nonaka, I. and Takeuchi, H. (1995), The Knowledge Creating Company: How Japanese Companies Create the Dynamics of Innovation, Oxford University Press, Oxford, USA, pp. $178-195$.

9. Penrose, E. (2018), The Theory of the Growth of the Firm, 3rd ed., Oxford University Press, Oxford, USA, pp. $21-26$.

Стаття надійшла до редакиї 26.05.2021 p. 